J. Clin. Chem. Clin. Biochem.

Vol. 20, 1982, pp. 175-180

\title{
Characterization of Two Anti-Human Parathyrin Antisera')
}

\author{
By H. Jüppner, R. Butz
}

Abteilung für Klinische Endokrinologie, Zentrum Innere Medizin, Medizinische Hochschule Hannover, FRG

M. Casaretto, H. Zahn

Deutsches Wollforschungsinstitut, Rheinisch-Westfälische Technische Hochschule, Aachen, FRG and

R.-D. Hesch

Abteilung für Klinische Endokrinologie, Zentrum Innere Medizin, Medizinische Hochschule Hannover, FRG

(Received July 14/December 7, 1981)

Summary: Two anti-human parathyrin antisera were raised in sheep. These were characterized by radioimmunoassay using two commercially available bovine parathyrin preparations and one synthetic human parathyrin fragment (sequence 42-55 (42-Tyr)) for radioiodination. In addition, four synthetic human parathyrin fragments (sequences $1-34,32-43,44-68,53-84$ ), one bovine parathyrin peptide (sequence $28-48$ ) and a human parathyrin standard from a tissue culture containing the intact hormone were utilized in a competitive inhibition assay against the two radiolabelled bovine parathyrin preparations. On column chromatography, both tracers revealed a difference in molecular weight, which is believed to be related to the extraction technique. The sequence fragment 44-68 of human parathyrin had the highest affinity for the two antisera when using the smaller molecular weight tracer and there were no qualitative changes observed in the presence of plasma. Using the higher molecular weight tracer, the addition of plasma to one of the antisera resulted in a higher affinity for the sequence fragment 1-34 of human parathyrin compared to that of intact parathyrin. Antiserum from a second sheep remained specific only for the mid-region (sequence 44-68) of the parathyrin molecule independent of the tracer used. Due to the antiserum's constant characteristic, it revealed a high reliability for the discrimination between plasma parathyrin levels in normal probands and in patients with hyperparathyroidism. Our data demonstrate that the specificity of the radioimmunoassay for human parathyrin is not exclusively dependent on the antibody source, but also on the tracer preparation and the protein content of the incubation medium.

\section{Charakterisierung von zwei Antiseren gegen humanes Parathyrin}

Zusammenfassung: Antiseren gegen humanes Parathyrin wurden durch Immunisierung von zwei Schafen hergestellt. Die Charakterisierung dieser Antikörper èrfölgte mit Hilfe von Rădioimmunoassays. Zwei kommerziell erhältliche bovine Parathyrin Präparationen, sowie ein synthetisch hergestelltes Fragment der humanen Parathyrinsequenz wurden radioaktiv markiert. Als Standardpräparationen dienten vier synthetische Fragmente des humanen Parathyrins (Sequenzen 1-34, 32-43, 44-68, 53-84), ein bovines Parathyrinpeptid (Sequenz 28-48) und ein aus Gewebekultur gewonnener humaner Parathyrinstandard, der das intakte Hormon enthält. Säulenchromatographische Ergebnisse zeigten ein unterschiedliches Molekulargewicht für die bovinen Tracerpräparationen, was möglicherweise auf unterschiedliche Extraktionsmethoden zurückzuführen ist. Bei Verwendung des niedermolekularen Tracers hatte die Sequenz 44-68 des humanen Parathyrins die höchste Affinität für beide Antiseren; bei Zusatz von Plasma traten keine qualitativen Assayveränderungen auf. Durch Verwendung des höhermolekularen Tracers konnte bei einem der Antiseren durch Zusatz von Plasma eine erhöhte Affinität für die Sequenz 1-34 des humanen Parathyrin erzielt werden. Unabhängig vom verwendeten Tracer blieb das zweite Antiserum spezifisch für die mittlere Parathyrinsequenz 44-68. Dieses Antiserum ist durch seine gleichbleibenden Eigenschaften besonders für Messungen im Plasma geeignet. Unsere Ergebnisse zeigen, daß die Spezifität eines Radioimmunoassays nicht nur vom jeweiligen Antikörper abhängig ist, sondern ebenfalls das radioaktiv markierte Hormon und der Proteingehalt des Inkubationsgemisches einen entscheidenden Einfluß auf die Hormonmessung haben.

\footnotetext{
1) Supported by a grant of the Deutsche Forschungsgemeinschaft (DFG) HE 593/11 and the Stiftung Volksivagenwerk $1 / 35519$.
} 


\section{Introduction}

Critical interpretation of radioimmunochemical determinations of human parathyrin requires knowledge of the specificity of the antibody for various parathyrin fragments. Three factors contribute to difficulties in the interpretation of parathyrin levels:

a) the heterogeneity of the antisera which have been produced (1),

b) the source of the labelled tracer and

c) the heterogeneity of circulating human parathyrin fragments $(1,2)$.

These circulating C-regional and mid-regional parathyrin fragments are generated to a considerable extent by peripheral cleavage of the intact parathyrin in the sequence region 33-42 (3). This suggests that the secretion rate of the intact parathyrin, which in itself has an extremely short half-life (4) may best be monitored by C-regional breakdown peptides with a prolonged circulation in plasma. Therefore, in clinical use, antibodies with a high affinity for these portions of parathyrin have been most useful for discriminating between normal and diseased status $(5,6,7)$. Two commercially available preparations of bovine parathyrin used in this study for radioiodination have been shown to elute differently on gel-filtration, thus exposing different antigenic sites for antibody interactions and thereby altering the assay specificity (8). Our studies were performed to further characterize two anti-parathyrin-antisera and to define the most constant antibody for parathyrin determinations in plasma.

\section{Materials and Methods}

\section{Antisera}

Two sheep (G III and C III) were immunized with approximately $200 \mu \mathrm{g}$ human parathyrin which was extracted as described (9) with trichloroacetic acid from human parathyroid adenomas. After chromatographic purification the hormone was diluted in distilled water to a final concentration of approximately $100 \mathrm{mg} / \mathrm{l}$ and was subsequently emulsified with an equal amount of complete Freund's adjuvant (Behring-Werke, Marburg/Lahn, FRG). Two milliliters of the mixture were injected intradermally at 15-20 sites on the backs of the animals. Each animal received a booster injection after 3 weeks and then again after 6 weeks. Three weeks after each booster, the sheep were bled and the anti-parathyrin titer was tested in the radioimmunoassay. For studies including the bovine parathyrin tracers the antisera were used in a final dilution of $1 / 26250$ (G III), and $1 / 5250$ or $1 / 8700$ (C III). For the experiments using the sequence fragment 42-55 (42-Tyr) of human parathyrin as a tracer, both antisera were used in a final dilution of $1 / 1750$.

\section{Iodination of bovine parathyrin}

Two preparations of highly purified bovine parathyrin were used for this investigation:

i) Lot no. 156552 from Wilson, Chicago, USA

ii) Lot no. $1515 \mathrm{Cool}$ from Inolex, Chicago, USA

Both hormones were iodinated with ${ }^{125}$ I (specific activity $296-555 \mathrm{GBq} / \mathrm{mg}(8-15 \mathrm{Ci} / \mathrm{mg}) \mathrm{NaI})$ by a modification of the method of Hunter \& Greenwood $(10,11) .5 \mu \mathrm{g}$ bovine parathyrin were incubated for 20 seconds with $18.5 \mathrm{MBq}(0.5 \mathrm{mCi})$ of $\mathrm{Na}^{125} \mathrm{I}$ and $25 \mu \mathrm{g}$ Chloramine $\mathrm{T}$ in a final volume of $30 \mu \mathrm{l}$.
(Chloramine $T$ and metabisulphite were dissolved, and hormone and $\mathrm{Na}^{125} \mathrm{I}$ were diluted in $50 \mathrm{mmol} / 1$ phosphate buffer, $\mathrm{pH} 7.6$ ). The reaction was stopped by adding $50 \mu$ of a solution containing $60 \mu \mathrm{g}$ metabisulphite. The mixture was immediately transfered to a dry cellulose column $(0.4 \times 3.5 \mathrm{~cm}$ ) (cellulose: Whatman CF 1). The free iodine was eluted with a buffer containing $0.025 \mathrm{~mol} / 1 \mathrm{Na}$-barbital, $0.004 \mathrm{~mol} / \mathrm{l} \mathrm{Na}$-acetate, $0.0045 \mathrm{~mol} / 1 \mathrm{NaCl}$ and $0.1 \mathrm{~g} / 1$ Merthiolate, $\mathrm{pH} 7.4$ (buffer A). To remove the partially purified radiolabelled hormone from the cellulose, the column was eluted with normal serum. The two peak fractions were further purified on Bio-Gel P10 ( $2.5 \times$ $30 \mathrm{~cm}$ ), equilibrated and eluted with $0.1 \mathrm{~mol} / 1$ ammonium acetate buffer, $\mathrm{pH} 4: 5$. The second major peak of each hormone preparation was used for the radioimmunoassay.

\section{Iodination of the sequence fragment $42=55$ (42-Tyr) of human parathyrin}

This peptide was radioiodinated according to the protocol for labelling the bovine parathyrin preparations, except that the separation of the labelled hormone and the free iodine was performed on Sephadex G-10 $(0.9 \times 1.8 \mathrm{~cm})$.

\section{Standards}

The following standards were used:

i) Tissue culture standard (P2 Hamburg) was described in more detail elsewhiere (12). By means of various biologicâl assays (the adenylate cyclase assay using human and bovine renal plasma membranes, the cytochemical assay and the labelied=antibodymembrane-assay (LAMA)), this standard was shown to contain approximately $126 \mu \mathrm{g} / 1$ 1-84 human parathyrin. However, when using antiserum $G$ IIII and Inolex traceri to compare the P2 parathyrin concentration with the 1-84 human parathyrin stand= ard 75/549 (from the National Institute of Biological Standard and Control, Mill Hill, London), a 1-84 human parathyrin con= centration $100 \mu \mathrm{g} / 1 \mathrm{P} 2$ was calculated. These data indicate that this material contains not exclusively the intact hormone, but also other parathyrin peptides with a higher affinity for antibody G III.

ii) Synthetic fragments of human parathyrin include the $1=34$, $44=68,32-43$ and the 53-84 region of the hormone.

iii) The synthetic $28-48$ fragment of bovine parathyrin.

Human parathyrin sequences $1-34,44-68,53-84$ and bovine parathyrin sequence $24-48$, synthesized by the solid phase method, were obtained from $M$. Rosenblatt, Boston, USA (13). The homogeneity of the peptides was proved by high performance liquid chromatography. Human parathyrin sequences $32-43$ and 42-55 (42-Tyn) were liquid synthesized by $H$. Zahn and M. Casaretto, and homogeneity was proved by ion-exchange chromatography. The amino acid composition of each peptide, determined after acid hydrolysis, confirmed the predicted amino acid ratios. The lyophylized peptides were dissolved in acetic acid $(0.01 \mathrm{~mol} / 1)$ and were stored in aliquots at $-20^{\circ} \mathrm{C}$. Each standard curve point was performed in duplicate.

\section{Radioimimunoassay}

The assay was performed as described by Hehrmann et al. (5, 11). The final volume of $350 \mu$ l consisted of $50 \mu 1$ standard, $100 \mu 1$ parathyrin tracerr (approx. 5000 counts/min) and $200 \mu l$ antibody. The tracer and the antibody were diluted in buffer B (buffer A containing $10 \mathrm{~g} / \mathrm{l}$ human serum albumin; from Behring-Werke, Marburg/Lahn, FRG). The standarids were either dissolved in the same buffer or in charcoal treated normal serum $(5,11)$. The standard and the antibody were preincubated for $18-24 \mathrm{~h}$ at $4^{\circ} \mathrm{C}$, until the tracer was added for another $48 \mathrm{~h}$ at $4{ }^{\circ} \mathrm{C}$. Bound and free hormone were separated by the addition of $2 \mathrm{ml}$ of ice cold Dextran-coated charcoal. This was prepared by mixing $1 \mathrm{~g}$ Dextran T 70 (Pharmacia, Uppsala, Sweden) and $10 \mathrm{~g}$ Norit A charcoal (Serva, Heidelberg, FRG) suspended in $400 \mathrm{ml}$ of buffẹer $A$ contaïning $25 \mathrm{~g} / 1$ human serum albumin. After 10 minutes of incubation at $4{ }^{\circ} \mathrm{C}$, the tubes were centrifuged for 15 minutes at $2800 \mathrm{~g}$ at $4{ }^{\circ} \mathrm{C}$. The bound and the free hormone were counted for radioactivity in an automatic gamma counter (Berthold, Wildbad, FRG̈). Data is expressed as 
$\mathrm{B} / \mathrm{B}_{0}$ (binding of the sample over maximal binding in the absence of cold hormone). Non-specific binding, which was determined in a separate control tube without the addition of antibody, is expressed as the fraction of radioactivity in the supernatant after charcoal separation compared to the total radioactivity. $B_{0}$ was calculated by dividing the difference in the number of counts of the bound and non-specific binding by the total counts added. The tubes for non-specific binding and maximal binding $\left(B_{0}\right)$ were incubated either with the addition of buffer $B$ or charcoal treated plasma, depending on the medium used for diluting the standards.

\section{Results}

\section{The effect of synthetic fragments on the binding of Inolex tracer to C III antiserum}

The specificity of the antiserum C III using the Inolex material as tracer was only minimally affected by the presence of parathyrin-free plasma. As shown in figure 1a, standards dissolved in buffer $B$ displaced 0.50 of the tracer at $0.046 \mathrm{nmol} / 1$ of the 44-68 human parathyrin fragment. As shown in figure $1 \mathrm{~b}$ the same
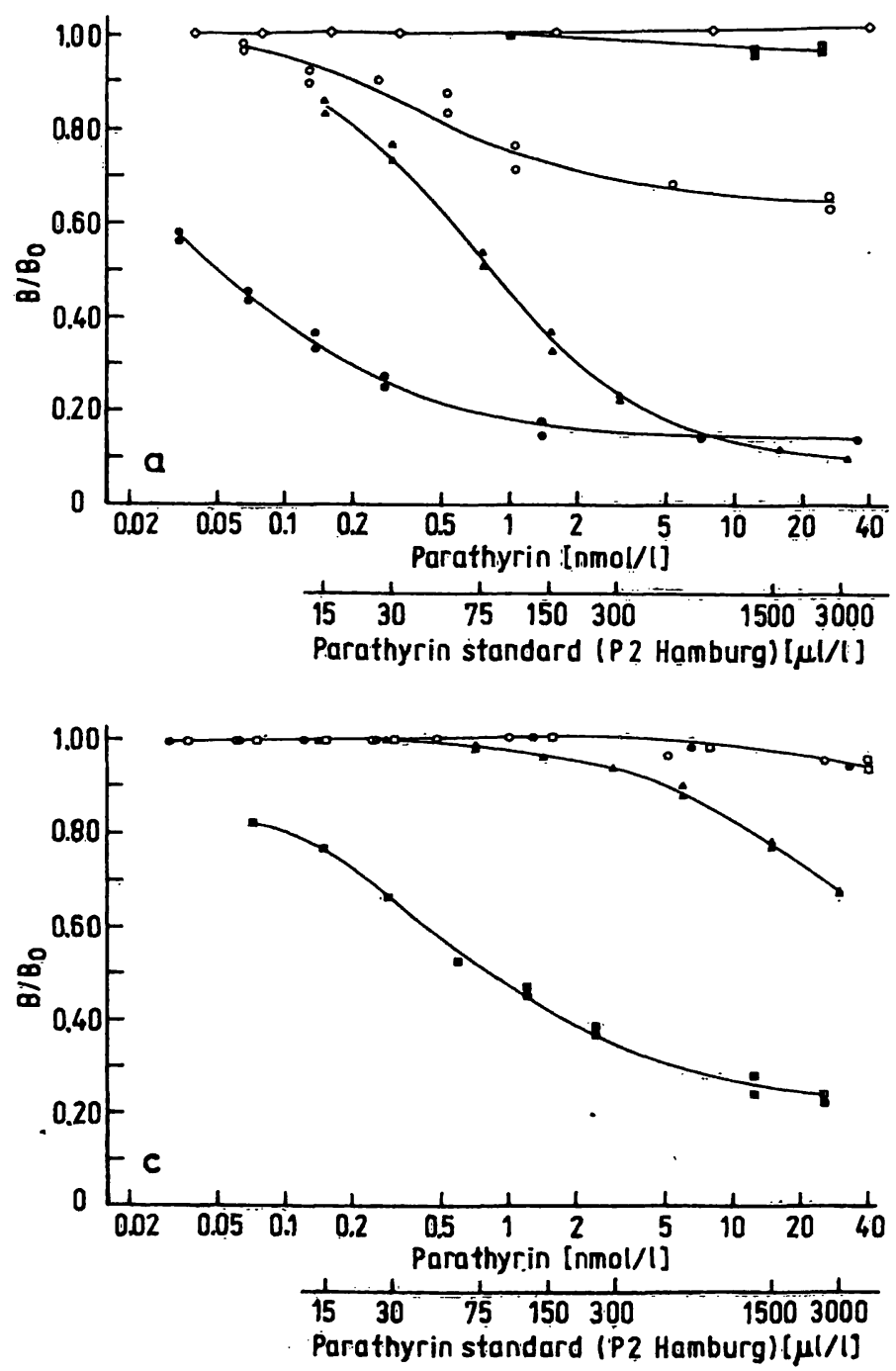

displacement was observed at $0.11 \mathrm{nmol} / 1$ when the peptide was dissolved in charcoal-treated plasma. Using the intact parathyrin (P2) 0.50 displacement was reached at P2 content of 80 and $100 \mu \mathrm{l} / 1$, respectively. The 53-84 fragment of human parathyrin displaced maximally at 0.35 of the tracer while the 1-34 human, $28-48$ bovine and the 32-43 human parathyrin had no influence on the tracer-antibody binding.

\section{The effect of synthetic fragments on the binding of the Wilson tracer to C III antiserum}

Using the Wilson preparation, entirely different results were obtained. As shown in figure 1c, dilution of the standards in parathyrin-free plasma decreased the sensitivity of the assay for the intact human parathyrin. Even at the highest standard concentration, only 0.35 of the tracer was displaced. Interestingly, $0.31 \mathrm{nmol} / 1$ 1-34 human parathyrin displaced the tracer to the same extent indicating a high affinity of the antibody for this fragment. Sequence fragments $28-48$ of bovine para-
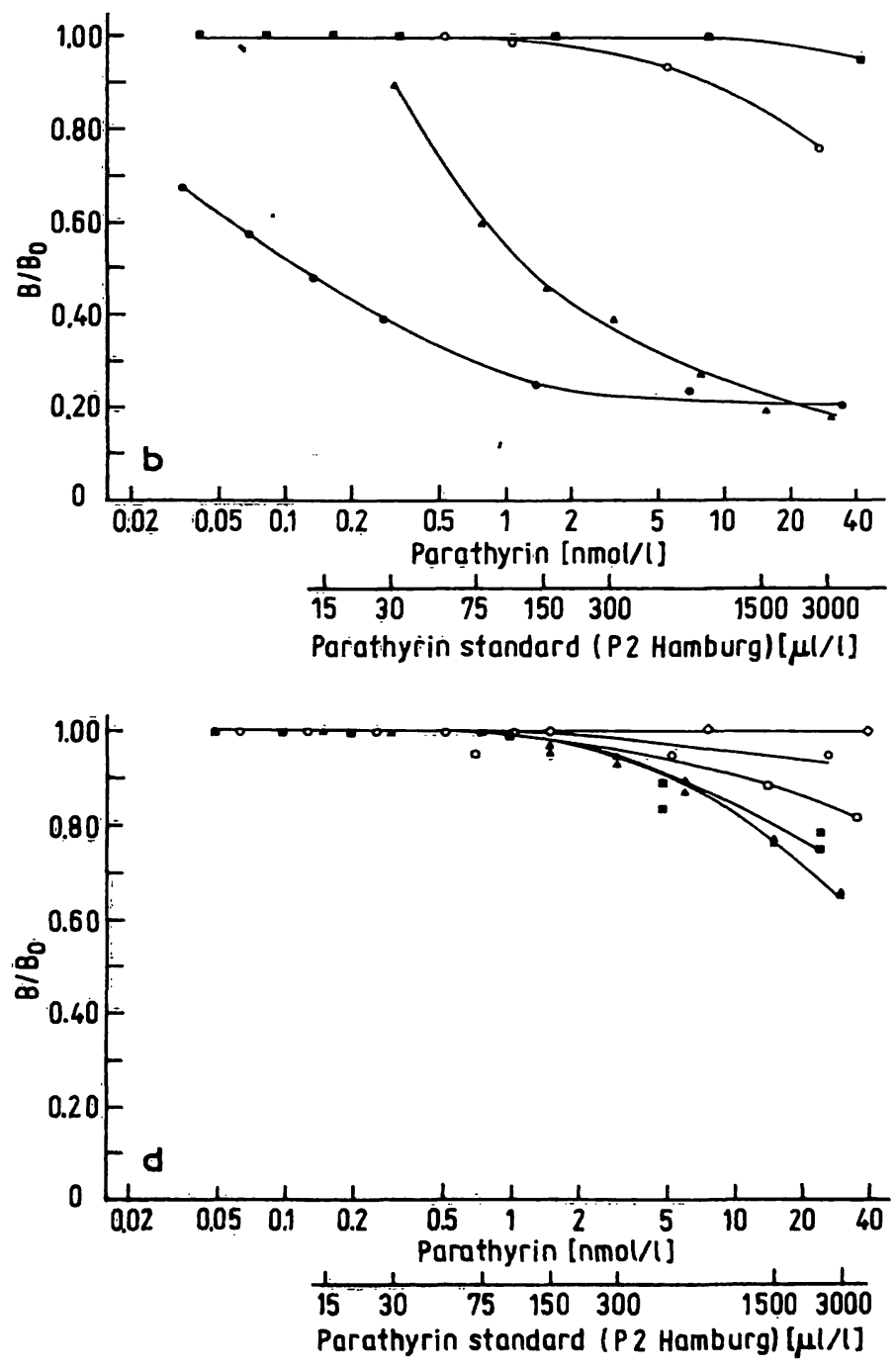

Fig. 1. Radioimmunoassays were performed using antiserum $C$ IIl in a final dilution of $1 / 8750(a-c)$, or $1 / 5250$ (d) with either the Inolex tracer $(\mathrm{a}, \mathrm{b})$ or the Wilson tracer $(\mathrm{c}, \mathrm{d})$. P2 (1-84 human parathyrin) (4- $)$ and parathyrin fragments which included the sequences $28-48$ of bovine parathyrin $(0-0), 1-34(--), 32-43(0-a), 44-68(\bullet-\bullet)$ and $53-84(0-0)$ of human parathyrin were dissolved either in parathyrin-free plasma $(b, c)$ or in buffer $B(a, d)$. 
thyrin, 32-43, 53-84 and 44-68 of human parathyrin showed an inability to displace the Wilson tracer. When the peptides were dissolved in buffer B, the assay remained insensitive for intact parathyrin and the different synthetic peptides (fig. 1d). Intact parathyrin at the highest concentration displaced 0.35 of the tracer comparable to the extent of displacement shown in figure 1c, where the hormone was dissolved in plasma. The potency of the fragments to displace the Wilson tracer decreased on a molar basis in the following order of sequences: $(1-34)>(32-43)>(44-68)>(28-48)>(53-84)$. In table 1 , a further difference between the two tracers is demonstrated for the non-specific binding and the specific binding. The non-specific binding of the Inolex preparation did not increase over 0.04 of the total radioactivity, even after three months of storage at $-20^{\circ} \mathrm{C}$. Different results were obtained with the Wilson material, which had a minimal non-specific binding of at least 0.116 with a freshly prepared tracer. The Inolex tracer exhibited a lower maximal specific binding with antiserum C III in the presence of plasma. The Wilson tracer showed the opposite reaction. At a final antiserum dilution of $1 / 5250, B_{0}$ was only 0.226 without the addition of plasma. Although the antibody dilution was increased to $1 / 8750, B_{0}$ increased to 0.415 when plasma was added to the tubes.

Tab. 1. Non-specific and maximal specific binding (fraction) of the tracers used.

\begin{tabular}{lllll}
\hline & \multicolumn{2}{l}{$\begin{array}{l}\text { Non-specific } \\
\text { binding } \\
\text { Plasma }\end{array}$} & Buffer & \multicolumn{3}{l}{$\begin{array}{l}\text { Maximal specific } \\
\text { binding } \\
\text { Buffer }\end{array}$} & Plasma \\
\hline $\begin{array}{l}\text { Inolex tracer } \\
\text { (final dilution of } \\
\text { antiserum C III) }\end{array}$ & 0.031 & 0.027 & $\begin{array}{l}0.312 \\
(1: 8750)\end{array}$ & $\begin{array}{l}0.171 \\
(1: 8750)\end{array}$ \\
$\begin{array}{l}\text { Wilson tracer } \\
\text { (final dilution of } \\
\text { antiserum C III) }\end{array}$ & 0.129 & 0.116 & $\begin{array}{l}.0 .226 \\
(1: 5250)\end{array}$ & $\begin{array}{l}0.415 \\
(1: 8750)\end{array}$ \\
\hline
\end{tabular}

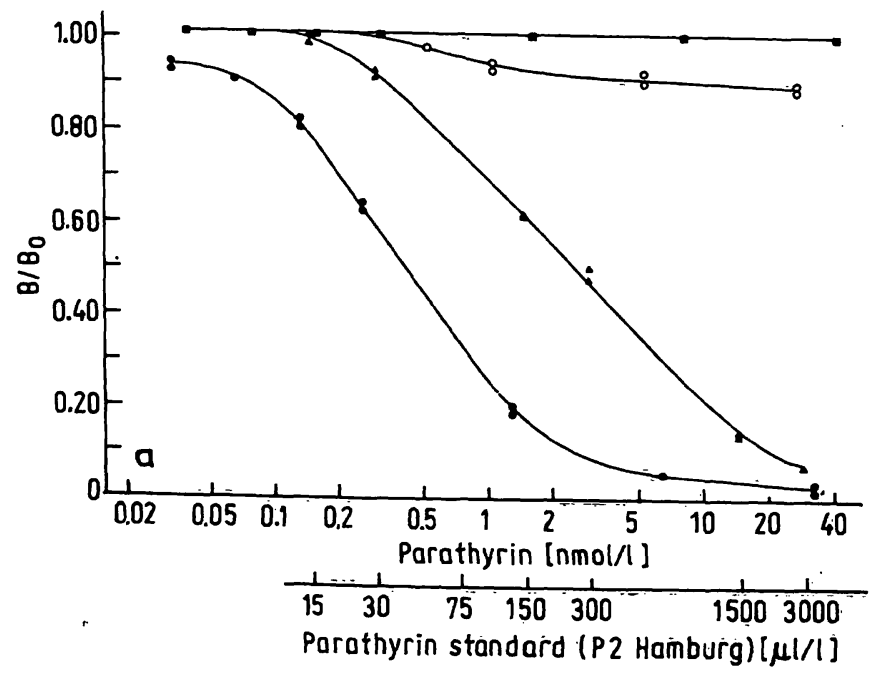

Effect of synthetic fragments on the binding of Inolex and Wilson tracer to G III antiserum

Using Wilson or Inolex tracer, the addition of plasma to G III assays had no effect on the specificity of the system. Therefore, this immunoserum was tested with the two tracer preparations using standards dissolved only in buffer $B$. As depicted in figures $2 a$ and $2 b$, there were no qualitative changes with either tracer used for the experiments. Similar to antibody C III, the 44-68 human parathyrin fragment had the highest affinity for the antibody. The protein concentration (standard dissolved either in buffer $B$ or in parathyrin-free plasma) did not alter the antibody specificity. Only in higher molar concentrations did the other fragments displace the tracēr. A slight decrease in sensitivity wàs ôbserved for the $44=68$ human parathyrin fragment when using the Inolex tracer. However, the overall reactivity was essentially similar compared with the standard curves dissolved in plasma.

\section{Binding of radiolabelled sequence 42-55 (42-Tyr) of human parathyrin to antibody $G$ III and $C$ III}

Both antibódies were used in a final dilution of $1 / 1750$. Only 0.033 (C III) and 0.012 (G III) respectively, of the total radioactivity were bound specifically to the antibody. Non-specific binding was 0.011 in this experiment.

\section{Gel-filtration of the Wilson and the Inolex tracer}

It is likely that the failure of the Inolex tracer to detect the $\mathrm{N}$-region of the parathyrin molecule might be due to a lack of constituents of the $1-34$ region. Therefore, the chromatographic elution patterns of both tracers were compared (fig. 3). The Inolex tracer elutes from the Bio-Gel P10 column at a later position than the Wilson material. This already indicates that the İnolex material may have a lower molecular weight than the Wilson material. Another investigator using the same Inolex

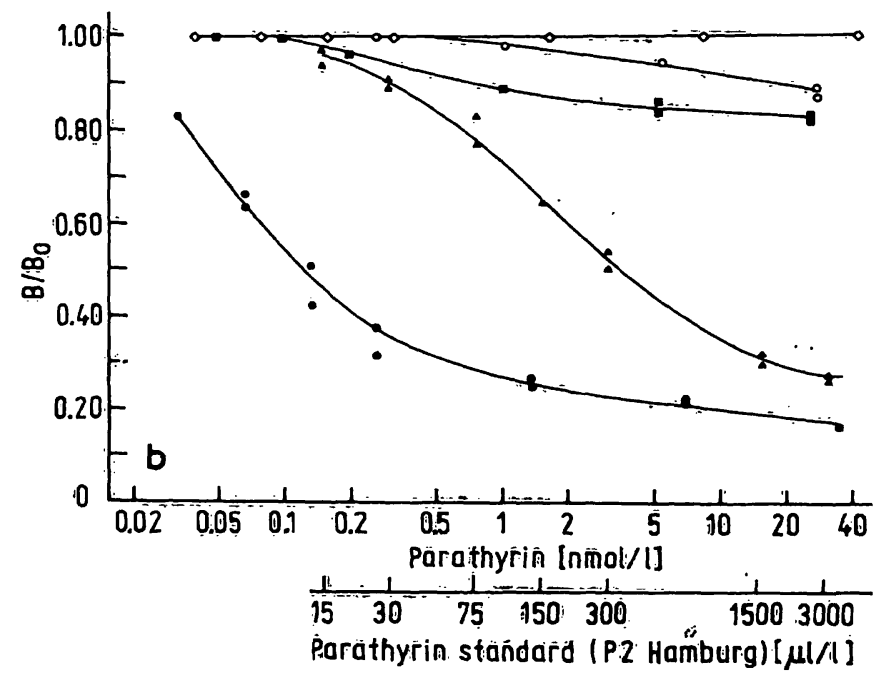

Fig. 2. Radioimmunoassays were performed using antiserum G III in a final dilution of $1 / 26250$ with either the Inolex (a) or the Wilson (b) tracer. P2 (1-84 human parathyrin) (4-1) and parathyrin which included the bovine 28-48. $(0-0)$, the

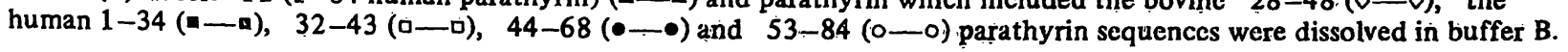


parathyrin for radioiodination demonstrated, by amino acid analysis, that this hormone preparation contains the 42-84 sequence of bovine parathyrin (14).

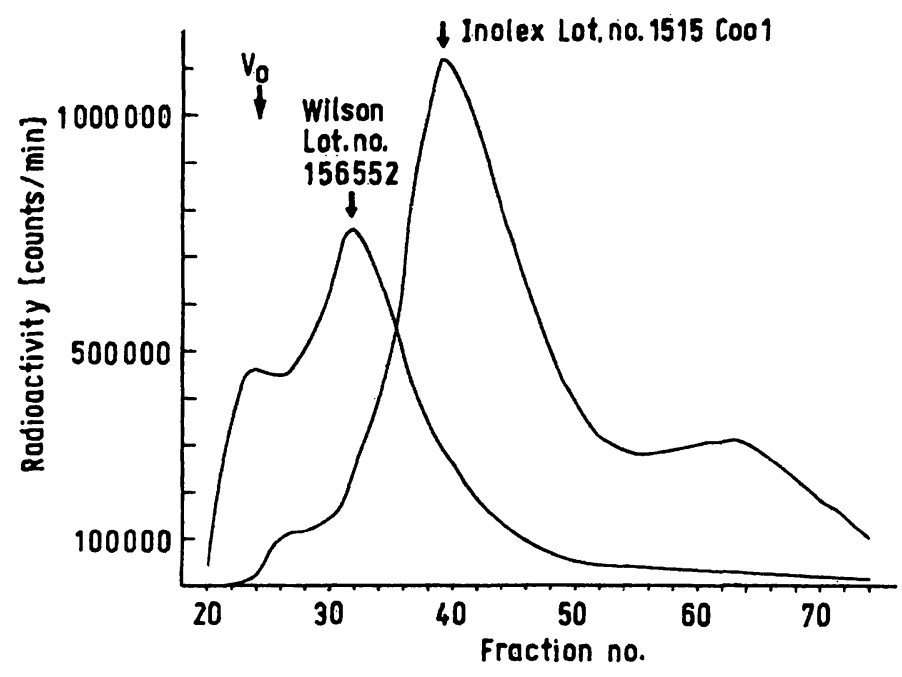

Fig. 3. The two tracer preparations used in this study were repurified on Bio-Gel P10 after an initial partial purification on a cellulose column. The second major peak of radioactivity of each tracer preparation was used for the radioimmunoassays.

\section{Discussion}

The radioimmunochemical determination of human parathyrin is still plagued by significant difficulties. Our data illustrates that the assay specificity is dependent upon at least three different components: the antibody source, the tracer preparation and the incubation milieu.

Similar to some antisera described recently $(5,6,8)$, both of our newly raised antibodies have the highest affinity for the mid-region of the parathyrin molecule (sequence 44-68) when using a mid-regional tracer. G III was already shown to be extremely useful in the discrimination between normal and elevated parathyrin plasma levels due to primary and secondary hyperparathyroidism (7). Antiserum C III, being more difficult to characterize, has not been used for extensive studies thus far. Our results suggest that the specificity of this antibody is dramatically affected by the choice of the tracer preparation. Using the $\mathrm{C}$-regional oriented tracer (Inolex), C III is most sensitive for the 44-68 peptide. However, with the intact tracer (Wilson), the assay becomes sensitive for the $\mathrm{N}$-terminal peptide $1-34$. Whether this change of specificity is related to conformational changes of the peptide induced by plasma protein, or is a result of decreased adsorption of the peptide to the surface of the incubation tubes (15) is unclear. This observation makes it likely that antiserum C III contains two distinctly different anti-parathyrinimmunoglobulins; one being anti-mid-regional (protein independent) the other being anti-N-terminal (protein dependent) with a relatively low titer. This would explain the decrease in maximal specific binding when performed in buffer. Most of the C III anti-parathyrin- immunoglobulin reacts preferentially with protions of the Inolex tracer (C-regional); therefore a high maximal binding is obtained at a final antibody dilution of $1 / 8700$. In contrast, when the assay was performed with the Wilson tracer, $\mathrm{B}_{0}$ decreased at a final antibody dilution of $1 / 5200$, thus illustrating a protein-dependent binding to the $\mathrm{N}$-terminal antibody portions. Additional experiments using a tyrosinated 1-34 (34-Tyr) human parathyrin tracer (unpublished data) showed a maximal specific binding of 0.264 at a final dilution of $1 / 1750$. These observations make it very likely that antiserum C III consists of at least two antibody idiotypes.

Antibody G III remained specific for the C-regional parathyrin independent of the tracer, which makes it very useful for clinical studies. However, slight changes in sensitivity due to the tracer were observed.

Our data illustrates that the assay specificity is also related to the protein content in the incubation mixture. Using the Wilson tracer, the characteristics of antiserum C III were influenced by plasma addition. Specific maximal binding increased more than twofold, while the non-specific binding remained nearly unchanged. This implies that plasma fractions facilitate the binding of the $\mathrm{N}$-regional oriented tracer to the antibody. The mechanism of this reaction, however, is unknown but seems to be restricted to $\mathrm{N}$-terminal oriented or intact tracers. In contrast, the $\mathrm{C}$-regional specific tracer exhibited no vulnerability to changes in plasma content, which has also been reported by other investigators (16). However, plasma seems not only to facilitate the binding of the $\mathrm{N}$-terminal tracer to the antibody, but also that of $\mathrm{N}$-terminal peptides, since the 1-34 peptide revealed a higher ability to displace the Wilson tracer. Whether these changes in affinity, for either the tracer or the standard, are related to changes in reactivity of the immunoglobulins, or to conformational effects on the tracer hormones is unknown. Changes in the conformation may be responsible for the inability of the iodinated sequence 42-55 (42-Tyr) of human parathyrin to bind to both antibodies. This was astonishing as this peptide covers most of the 44-68 human parathyrin sequence. The $28-48$ bovine parathyrin and the 53-84 human parathyrin (both including parts of the 44-68 sequence) are almost unable to displace either of the tracer preparations. Therefore, distinct conformational requirements for peptide-antibody interactions are to be expected. Similar observations have already been described for the 1-12 fragment of human parathyrin (17), thus confirming this explanation. No explanation can yet be offered for the increased non-specific binding of the Wilson tracer. However, the tracer binding to plasma components should be considered (18). This also would imply that only $\mathrm{N}$-terminal parts of the parathyrin molecule have a high affinity for plasma fractions, while mid-and C-regional fragments are only weakly attached to proteins (16). 


\section{Conclusion}

Our findings demonstrate that antibody G III is very useful for the determination of $\mathrm{C}$ - and mid-regional parathyrin fragments containing the sequence 44-68, independent of the tracer preparation and the protein content of the assay system. Antibody C III is an interesting antiserum, which could be used under well- defined incubation conditions for the detection of $\mathrm{N}$-terminal and intact parathyrin. Parathyrin from tissue culture is shown to be extremly useful for routine parathyrin radioimmunoassays and might provide better interlaboratory comparison than pooled hyperparathyroid sera, since this hormone preparation can be produced in large quantities.

\title{
References
}

1. Segre, G. V., Tregear, G. W. \& Potts, J. T. jr. (1975) Meth. Enzymol. $X X X V I I B, 38-66$.

2. Berson, S. A. \& Yalow, R. S. (1968) J. Clin. Endocrinol. Metab. 28, 1037-1047.

3. Segre, G. V., Niall, H. D., Habener, J. F. \& Potts, J. T. (1974) Am. J. Med. 56, 774-784.

4. Parsons, J. A. (1976) In: The Biochemistry and Physiology of Bone (Bourne, G. A., ed.) Academic Press, New York

5. Hehrmann, R. (1980) Plasma-Parathormon. Methodik, Pathophysiologie und Klinik, Urban \& Schwarzenberg, München-Wien-Baltimore.

6. Gallagher, J. C., Riggs, B. L., Jerpbak, C. M. \& Arnaud, C. D. (1980) J. Lab. Clin. Med. 95, 373-385.

7. Wood, W. G., Butz, R., Casaretto, M., Hehrmann, H., Jüppner, H., Marschner, I., Wachter, Ch., Zahn, H. \& Hesch, R. D. (1980) J. Clin. Chem. Clin. Biochem. 18, 789-795.

8. Mallette, L. E. (1980) J. Clin. Endocrinol. Metab. 50, 201-203.

9. Littledike, E. T. \& Hawker, C. D. (1967) Endocrinology 81 , $261-266$.

10. Hunter, W. M. \& Greeniwood, F. C. (1962) Nature (Lond.) $194,495-496$.

11. Hehrmann, R., Wilke, R., Nör̆dmeyer, J. P. \& Hesch, R. D. (1976) Dtsch: Med. Wochenschr. 101, 1726-1728.

12. Domn-Quint, G., Montz, R., Dietel, M. \& Mohr, H. (1980) Acta Endocrinol. (Kbh), Suppl. 234, 120-121.

13. Rosenblatt, M., Tregear, G. W., Shepard, G. L., Tyler, G. A., Veroni, M. \& Potts, J. T. jí. (1980) Arch. Biochem. Biophys. 199, 286-296.

14. Màllette, L. E. (1981) Horm. Metäb. Res. 13, 523-528.

15. Jüppner, H., Mohr, H. \& Hesch, R. D. (1980) J. Ćlin. Chem. Clin. Biochem. 18, 585-590.

16. Immuno Nuclear Corporation, Stillwater, Minnesota 55082 , USA (1980).

17. Habener; J. F. \& Potts, J. T. jr. (1979) Endocrinology 105, 115-119.

18. Segre, G. V., Niall, H. D., Sauer, R. T. \& Potts, J. T. jr. (1977) Biochemistry 16, 2417-2427.

\author{
Harald Jüppner \\ Abt. für Klin. Endokxinòlogie \\ Zentrum Innëre Medizin \\ Medizinische Hochschule Hannòver \\ Karl-Wiechèrt-Allee 9 \\ D-3000 Hannover 61
}

